\title{
Characteristics of Hydro-Oceanography in the Coastal Waters of Kura-Kura Beach, Bengkayang Regency
}

\author{
Muhardi $^{1}$, Risko ${ }^{2}$, Heni Susiati ${ }^{3}$ \\ Tanjungpura University, Indonesia ${ }^{1,2}$, National Atomic Energy Agency, Indonesia ${ }^{3}$ \\ muhardi@physics.untan.ac.id ${ }^{1}$, risko@physics.untan.ac.id ${ }^{2}$, heni_susiati@batan.go.id ${ }^{3}$
}

Received: September $2^{\text {nd }}, 2020$. Revised: September $23^{\text {rd }}, 2020$. Accepted: October $2^{\text {nd }}, 2020$

\section{Keywords :}

Tidal; Ocean Waves; Current

Velocity; Coastal Waters of

Kura-Kura Beach

\begin{abstract}
The waters of Kura-Kura Beach have quite a lot of human activities, one of which is tourism. The study aims to observe Hydro-Oceanographic parameters such as tidal conditions, ocean currents, and waves. The study uses field observation data and simulation results. The data is calculated to find Formzhal number based on the amplitude of tidal harmonic constants. The Flow analysis to determine the pattern and velocity of the current. The height and period of the wave to analyze characteristics of the wave. The results show that the tide in Kura-Kura Beach waters is a daily mix of a double with the highest tide at MSL and a minimum tide of 0.43 below MSL. While the current velocity obtained from the yield model has a range of $(0.003-0.11) \mathrm{m} / \mathrm{s}$, and the measurement results are between $(0.005-0.14) \mathrm{m} / \mathrm{s}$. The simulation results show that the current moves from land to sea at low tide, and it moves from sea to land at toward the tide. For the height of the ocean waves that are formed in a period of 10 years (2009 - 2019) ranges from (0.09 - 154) $m$ and the wave period (1.86 - 5.73) seconds. Based on the calculation results, the largest wave energy occurs in the second intermediate period, namely 184.21 Joules $/ m$ with height and wave periods of $1.21 \mathrm{~m}$ and 4.39 seconds. In contrast, the smallest wave energy occurs in the first intermediate period with minimum wave height and period $0.18 \mathrm{~m}$ and 3.08 seconds. In general, based on the simulation of the current velocity model, the forecasting of wave height and wave energy in Kura-Kura Beach waters is still relatively small. So, it can be concluded that the location is still categorized as safe for coastal tourism and other activities.
\end{abstract}

\section{INTRODUCTION}

The Coastal waters of Kura-Kura Beach are waters located in Bengkayang Regency, West Kalimantan, where there are many human activities in this area, one of which is coastal tourism. Apart from that, another problem in the area is also close to the traffic activities of ships carrying coal for the Steam 
Electric Power Station (PLTU). It is necessary to study the waters' hydro-oceanographic characteristics, which are useful as information for human activities. Theoretically, the coast is a zone of contact and interaction between land and sea, continuously changing. This is caused by several factors, including external and internal influences, both natural and human activities. Natural elements are influenced by hydro-oceanographic factors such as tides, ocean currents, and waves. Meanwhile, human activities are influenced by coastal areas such as tourism, industry, fisheries, ports, mining, settlements, and river closures [1] [2].

In general, several things affect the coast's physical changes, including tides, ocean currents, waves, and winds. Tide data can generate mass flows of water or currents are utilized in shipping routes and are useful for monitoring tsunamis, tidal storms, ship navigation, coastal engineering, and coastal management. The speed of tidal currents in the coastal area is more significant than in the high seas because the flow accelerates due to the horizontal and vertical narrowing by the shallow seabed and coastal topography. While wave data is used when sailing, to maintain safe sailing conditions and times are not recommended for sailing [3] [4]. Meanwhile, waves can damage and shape the beach, thus affecting buildings on the beach. Wave energy can cause currents and interfere with sediment movement perpendicular to the coast and parallel to the coastline [5] [6]

A study on seasonal flow modeling in the Lemukutan waters of West Kalimantan, which showed that these waters had a mixed predominantly diurnal tidal type with flow velocities ranging from $0.2-0.5$ $\mathrm{m} / \mathrm{s}$ [7]. The current velocity value is close to the results regarding oceanographic parameters' characteristics that were conducted in the North and South Waters of Bangka Island, which produce current velocities ranging from $0.2-0.3 \mathrm{~m} / \mathrm{s}$ and wave heights ranging from $0.1-0.5 \mathrm{~m}$ [8]. A similar study regarding tidal and wave characteristics was conducted in the waters of Saleh Bay, West Nusa Tenggara. It has a tidal type mixed mainly semidiurnal and significant wave heights reaching 1 meter in the west season, first transition, and east monsoon [9]. Meanwhile, in the second transitional season, it only reaches $0.5 \mathrm{~m}$. From some of the research results, there are various hydro-oceanographic characteristics in each water area. This study aimed to determine the characteristics of the hydrooceanographic in Kura-Kura Beach, Bengkayang Regency. There are several methods for analyzing the characteristics of hydro-oceanographic parameters in water, namely hydro-oceanographic modeling, which is validated by field observation results.

\section{METHOD}

The location of this research was carried out in the coastal waters of Kura-Kura Beach, Bengkayang Regency (Figure 1). The data used in this study are tidal data for the month obtained from the tidal calculation method using the Tidal Model Driver (TMD) and Admiralty methods. The TMD method is used to generate tide prediction data and the values of the tide components used in calculating the Formzahl (F) formula in determining the type of tide at the study site [10]. The type of tide seen from the Formzahl number value is then calculated based on the amplitude of the tidal harmonic constant $K_{1}, O_{1}, M_{2}$, and $S_{2}$ using the Equation 1 [11]:

$$
F=\frac{K_{1}+O_{1}}{M_{2}+S_{2}}
$$

The current and wave data were each measured for four days from 11 - 14 April 2019. The data from these measurements were used to validate the model results. In processing wave data, the wave parameters are obtained, namely wave height $(\mathrm{H})$ and wave period $(\mathrm{T})$, then analyzed using the representative wave determination calculated by the Equation 2, 3 and 4 [12] :

$$
\begin{gathered}
n=33,3 \% \times n \\
H_{S}=\frac{H_{1}+H_{2}+H_{3}+\cdots+H_{n}}{n}
\end{gathered}
$$


JIPF, Vol. 6 No. 1, January 2021

$$
T_{S}=\frac{T_{1}+T_{2}+T_{3}+\cdots+T_{n}}{n}
$$

Where :

$H_{s} \quad=$ The significant wave height (m)

$T_{s} \quad=$ The significant wave period $(\mathrm{dt})$

$H_{1 \ldots n}=$ Wave height to $n(\mathrm{~m})$

$T_{1 \ldots n}=$ Wave period to $n(\mathrm{dt})$

The wind data is obtained from ECMWF (European Centre for Medium-Range Weather Forecasts) in 10 years (2009 - 2019). The output of this EMWF data is wind speed and direction, which is the result of re-analysis and interpolation of meteorological data at an altitude of $10 \mathrm{~m}$ above sea level, which is used for wave prediction. The determination of fetch in wave forecasting uses wind direction and speed data. The effective fetch length is calculated using the Equation 5 [13]:

$$
F_{\text {eff }}=\frac{\sum x_{i} \cos \alpha}{\sum \cos \alpha}
$$

Where $F_{e f f}, x_{i}$, and $\alpha$ are the effective fetch length $(\mathrm{km})$, the fetch length for each cardinal direction (m) and the angle between the directions measured by fetch line $\left({ }^{0}\right)$, respectively. Then to calculate the wave energy using the Equation 6 [14]:

$$
E_{g e l}=\frac{1}{8}\left(\rho g H_{s}^{2}\right)
$$

Where $\rho$ is the density of water $\left(1030 \mathrm{~kg} / \mathrm{m}^{3}\right), g$ is the acceleration due to gravity $\left(9,8 \mathrm{~m} / \mathrm{s}^{2}\right)$, and $H_{s}$ is the significant wave height.
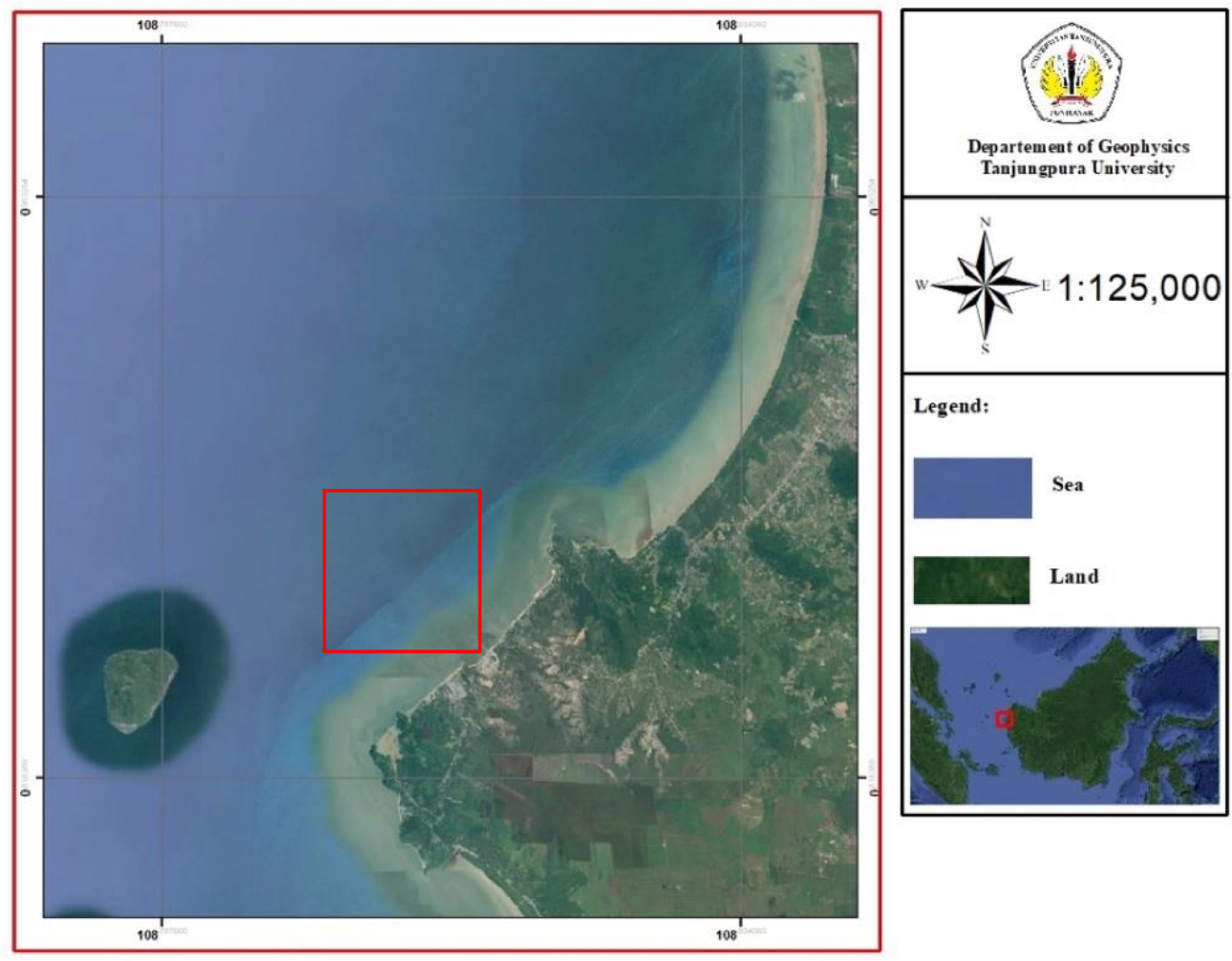

Fig 1. Map of Research Locations in the Coastal Waters of Kura-Kura Beach 


\section{RESULTS AND DISCUSSIONS}

Tide

The tidal model was run for 30 days (11 April - 10 May 2019) and validated with the measurement results from Geospatial Information Agency (BIG) in the coastal waters of Kura-Kura Beach, Bengkayang Regency (Fig. 2). The sea level height from this model is analyzed using $t_{-}$tide to obtain the amplitude and phase of the four main components of the tide, namely $M_{2}, S_{2}, K_{1}$, and $O_{1}$. The admiralty analysis that has been carried out shows the tidal main harmonic constants, as shown in Table 1.

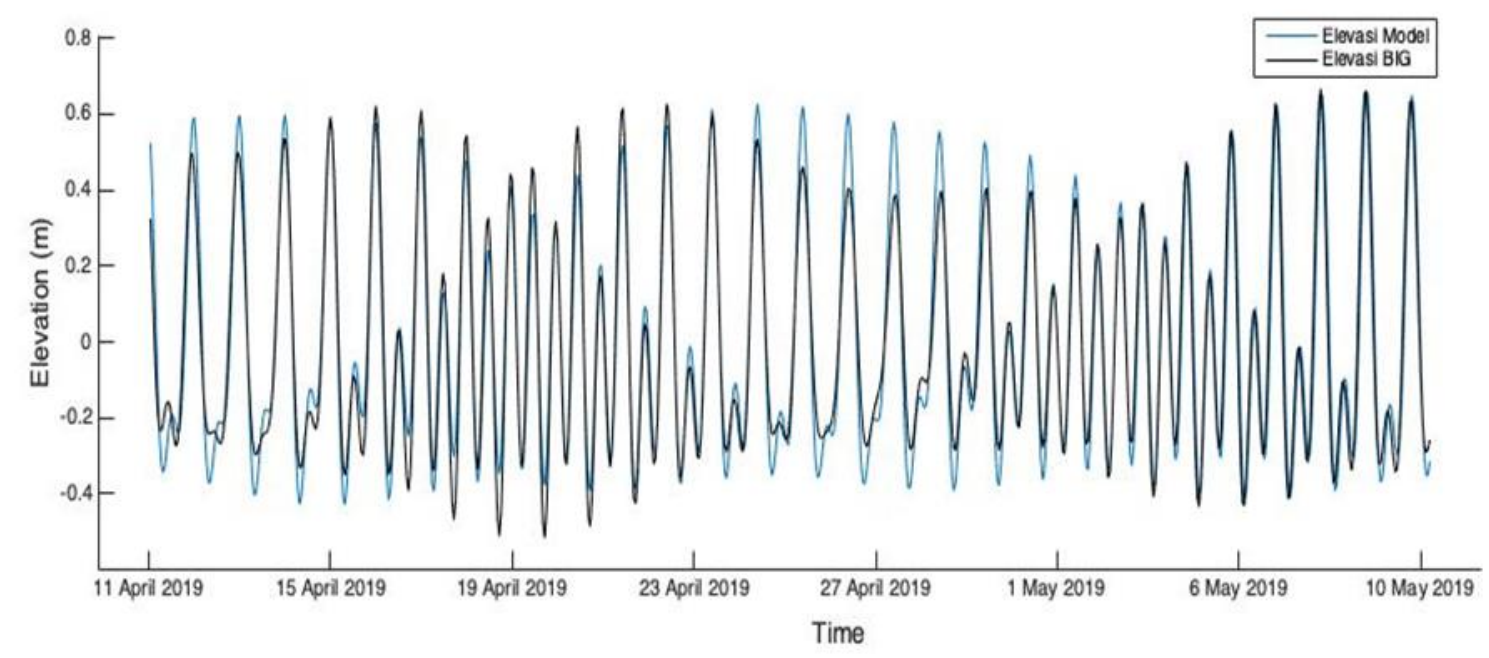

Fig 2. Tidal Validation of Model Results and BIG Results

From the tidal results obtained, the Mean Sea Level (MSL) in Kura-Kura Beach waters is $1.13 \mathrm{~m}$, where the highest tide is $0.67 \mathrm{~m}$ above the MSL, and the lowest tide is $0.43 \mathrm{~m}$ below the MSL. The level of sea level is influenced by several factors, including the topography of the seafloor, the width of the strait, and the shape of the bay [8]. The constant of the harmonic component of the sea level height in the waters of Kura-Kura Beach, the Formzahl number, is obtained as $1.12(0.25<\mathrm{F} \leq 1.5)$. This value indicates that the type of tide in Kura-Kura Beach waters is type mixed tide prevailing semi-diurnal, wherein a day there will be two high tides and two low tides with different heights and periods. This type of tide is in accordance with the results of research by Apriansyah, et al [15] in the waters of the Batu Burung Singkawang.

Table 1. The Main Component of Tides in Coastal Waters of Kura-Kura Beach

\begin{tabular}{ccc}
\hline Tidal Component & Amplitude & Phase \\
\hline$M_{2}$ & 0.3051 & 262.88 \\
$S_{2}$ & 0.0892 & 298.23 \\
$K_{1}$ & 0.2105 & 347.09 \\
$O_{1}$ & 0.2342 & 271.95 \\
\hline
\end{tabular}

\section{Current Velocity}

Based on the simulation results of the current model in the coastal waters of Kura-Kura Beach, the fluctuation in current velocity ranges from $(0.003-0.11) \mathrm{m} / \mathrm{s}$ (Figure 3$)$. The results of this model are close to the results obtained from field measurements for three days (11-13 April 2019) with a maximum current of $0.14 \mathrm{~ms}$ and a minimum current of $0.005 \mathrm{~m} / \mathrm{s}$. These results indicate that the current velocity is relatively small. This is because the simulation calculations of the model results and field data collection were carried out in April. The results obtained are close to the results conducted by Tarhadi, et al [7] regarding the modeling of seasonal flows in the Lemukutan waters of West Kalimantan, a maximum current of $\sim 2 \mathrm{~m} / \mathrm{s}$ is obtained, which states that in April, the ocean currents tend to be calmer 
because the position of the sun around the equator makes pressure differences air in the North and South, resulting in relatively small wind speeds. The visible current velocity also has a tendency that is almost the same as the tidal pattern that occurs. Thurmann states that if the current pattern in water shows a pattern that follows the tidal pattern, it can be said that tidal currents are the dominant currents in these waters [16].

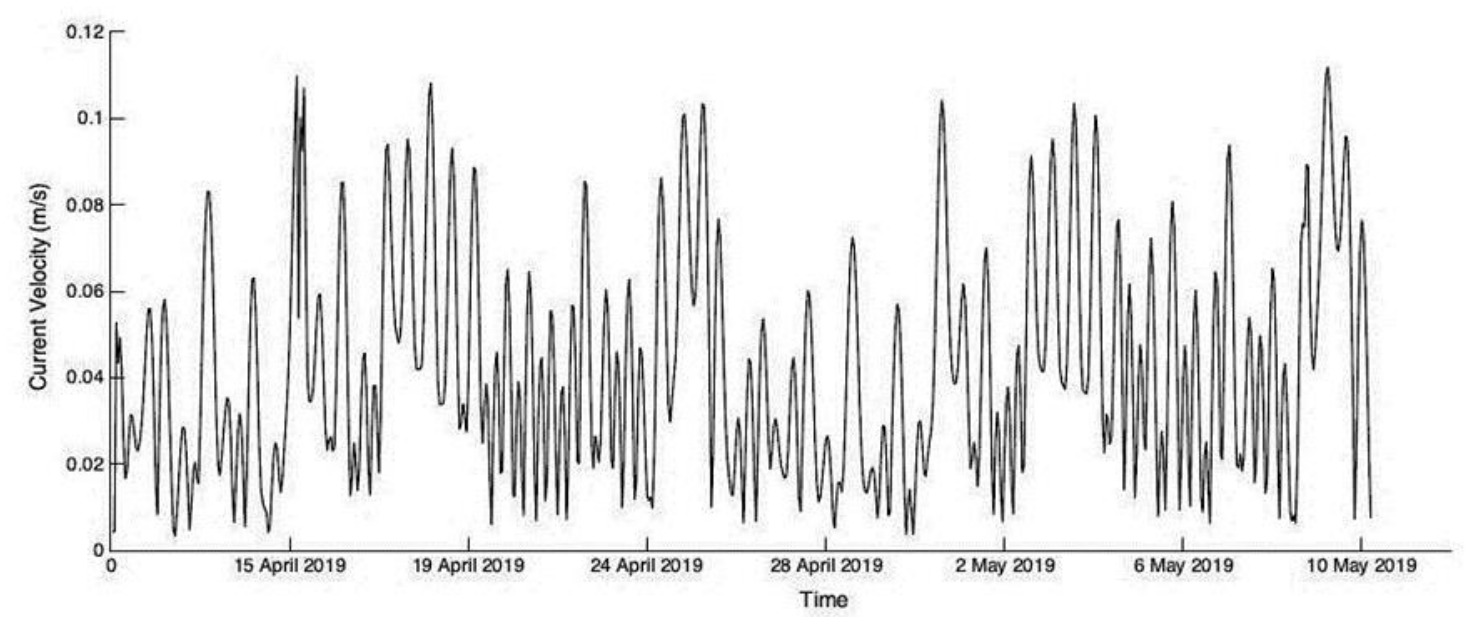

Fig 3. Current Velocity Profile in the Coastal Waters of Kura-Kura Beach
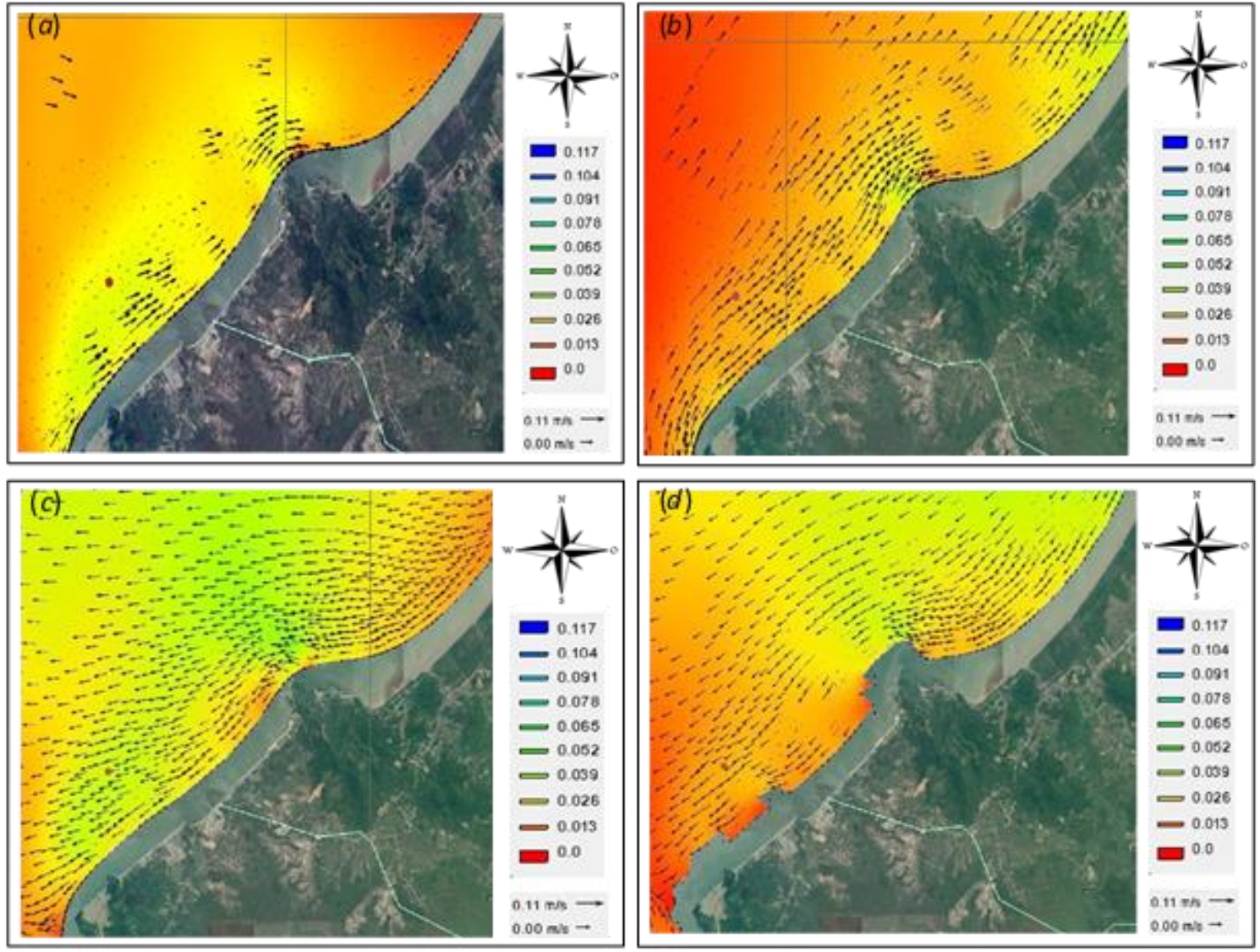

Fig 4. The Simulation Results of the Velocity and Direction of the Current Model Under Conditions (a) Low Tides Towards High Tides; (b) High Tides; (c) High Tides Towards Low Tides; (d) Low Tides

Figure 4 shows the speed and direction of the current movement in Kura-Kura Beach waters at low tides towards high tides, high tides, high tides towards low tides, and low tide. The maximum velocity and 
direction of the current at high tide is $0.07 \mathrm{~m} / \mathrm{s}$ with the direction of the current moving north, while at low tide, the current speed reaches $0.053 \mathrm{~m} / \mathrm{s}$ to the south-southwest. At low tide, the minimum current velocity obtained is $0.11 \mathrm{~m} / \mathrm{s}$ with the direction of the current moving to the southwest, while at low tide, the current reach $0.07 \mathrm{~m} / \mathrm{s}$ to the north (Table 2). The current moves from land to sea at low tide, and it moves from sea to land at toward the tide. The current movement pattern shows that the flow pattern that moves follows the tidal movement pattern that occurs in these waters. Tarhadi states that during low tide, the sea level is lower than the average sea level so that the current flows away from the beach and vice versa at high tide, the current flows closer to the beach [17].

Table. 2 Speed and Direction of Currents in the Coastal Waters of Kura-Kura Beach

\begin{tabular}{ccc}
\hline Tidal Conditions & Current Velocity $(\mathbf{m} / \mathbf{s})$ & Current Direction \\
\hline High tides & 0.08 & North \\
High tides towards low tides & 0.053 & South Southwest \\
Low tides & 0.11 & Southwest \\
Low tides towards high tides & 0.07 & North \\
\hline
\end{tabular}

\section{Wave Characteristics}

Forecasting the height and period of ocean waves can be done by using wind direction and speed data as the main factors for generating ocean waves. According to Mardiansyah, et al [18], the presence of wind will affect the amount of energy density produced because wave energy is the rise and fall of sea level where the water surface is influenced by wind gusts, which then affects the generation of waves. Wave forecasting can be determined using the calculation of the wind stress factor and fetch length so that the height and period of the ocean waves can be determined [19] [20] [21]. The average height and period of sea waves that form in the coastal waters of Kura-Kura Beach for ten years (2009 - 2019) from each season are presented in Table 3.

Table 3. Height and Wave Period in Each Season

\begin{tabular}{ccc}
\hline Monsoon & $\mathbf{H}_{\mathbf{s}}(\mathbf{m})$ & $\mathbf{T}_{\mathbf{s}}(\mathbf{s})$ \\
\hline West & 0.21 & 3.68 \\
Intermediate I & 0.18 & 3.08 \\
East & 0.19 & 3.39 \\
Intermediate II & 1.21 & 4.39 \\
\hline
\end{tabular}

The height of the sea waves that formed in the coastal waters of Kura-Kura Beach in the ten years (2009 - 2019) ranged from $0.09-1.54 \mathrm{~m}$, and the ocean wave period ranged from $1.86-5.73$ seconds. The results of the calculation of waves from each season that have a maximum wave height are in the second intermediate period (September - November) with an average value of $1.21 \mathrm{~m}$ and 4.39 seconds. Meanwhile, the smallest significant wave height and period occurred in the first intermediate period (March - May) with an average value of $0.18 \mathrm{~m}$ and 3.08 seconds. Based on the validation of the results of field measurements taken in April, it shows that the forecast results for height and wave period are close to the results of field calculations (Table 4). Based on the range of the period value (0.2 - 9 seconds) the wave is included in the wind wave [21].

Furthermore, from the calculation of sea wave energy in the coastal waters of Kura-Kura Beach, it is found that the greatest energy value occurs in the second intermediate period (September - November), namely $1849.21 \mathrm{Joule} / \mathrm{m}$. Meanwhile, the lowest wave energy value occurs during the first intermediate period (March - May), namely $40.92 \mathrm{Joules} / \mathrm{m}$. The amount of wave energy can affect or change the shoreline in the form of abrasion [11]. The greater the wave height in the water, the greater the energy produced. From Figure 6, it can be seen that there are fluctuations in the ups and downs of the wave heights that occur every year in 10 years $(2009$ - 2019). Thus, the energy density is influenced by the distribution of wind at sea level, the wind will affect the amount of wave energy density produced, the greater the wind at sea level, the greater the density of wave energy produced [19]. 
JIPF, Vol. 6 No. 1, January 2021

Table 4. Comparison of Wave Height and Period Based on Field Data and Forecasting

\begin{tabular}{ccc}
\hline Wave Data & Field Measurements & Forecasting \\
\hline $\mathrm{H}_{\mathrm{s}}$ & 0.21 & 0.18 \\
$\mathrm{~T}_{\mathrm{s}}$ & 4.54 & 3.08 \\
\hline
\end{tabular}

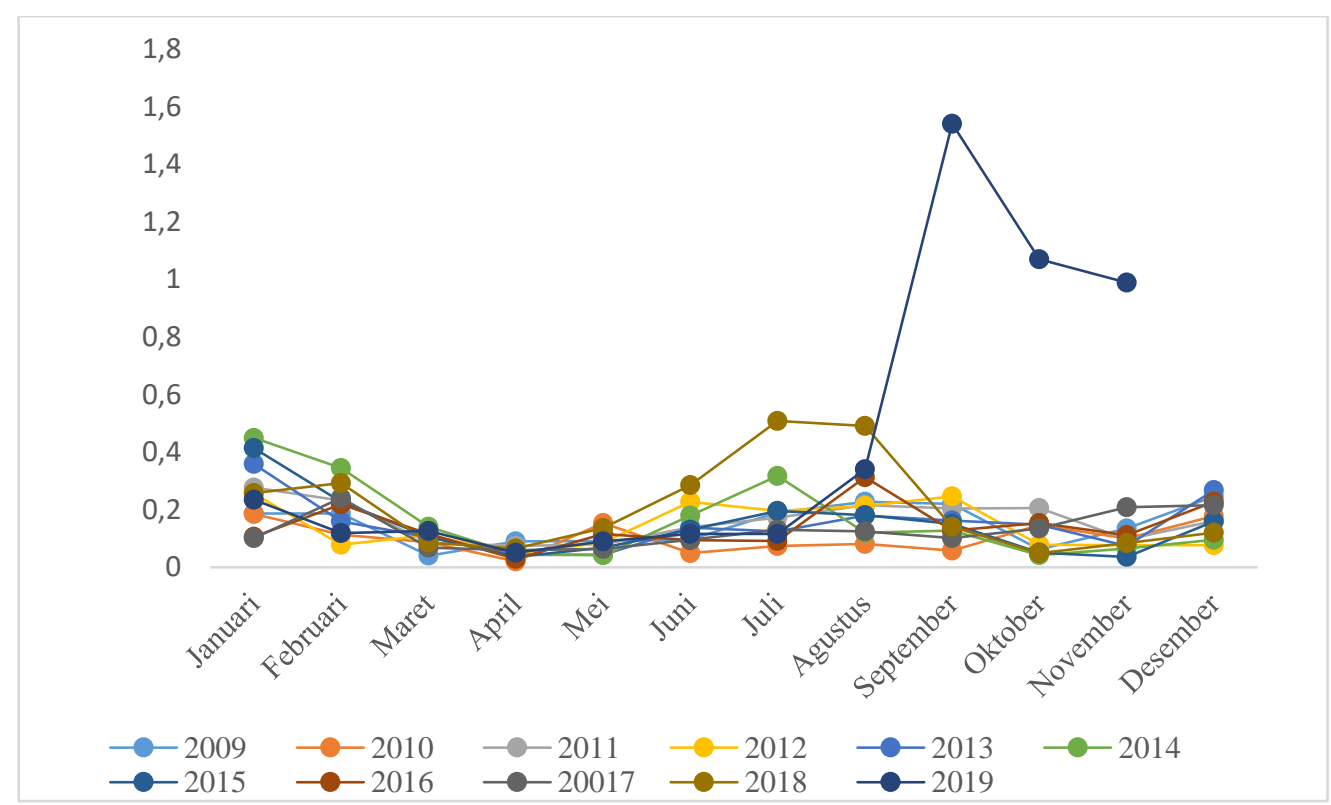

Fig 6. Average Wave Height in the Coastal Waters of Kura-Kura (2009-2019)

\section{CONCLUSION AND SUGGESTION}

Based on validated model simulations with the results of field measurements of characteristics hydrooceanography in the coastal waters of Kura-Kura Beach from the tidal parameters, the Mean Sea Level (MSL) is $1.13 \mathrm{~m}$ with high tides of 0.067 above MSL and a low tides of 0.43 below MSL. As for the type of tide in these waters, the mixture tends to double daily. From the model simulation results, the current velocity is between $(0.003-0.11) \mathrm{m} / \mathrm{s}$. These results are not much different from the results obtained from field measurements, which range from $(0.005-0.14) \mathrm{m} / \mathrm{s}$. The model simulation results show the direction of the current at low tide, the current moves toward the sea, and when the condition is toward the tide, the current moves from the sea to the land. Then for wave characteristics, the height of the ocean waves formed for ten years $(2009$ - 2019) ranges from $(0.09$ - 154) $\mathrm{m}$ and the wave period (1.86 - 5.73) seconds. Based on the calculation results, the largest wave energy occurs in the second intermediate period, namely $184.21 \mathrm{Joules} / \mathrm{m}$ with height and wave periods of $1.21 \mathrm{~m}$ and 4.39 seconds, and the smallest wave energy occurs in the first intermediate period with minimum wave height and period of $0.18 \mathrm{~m}$ and 3.08 seconds. In general, from the simulation results of the current velocity model, the prediction of wave height and wave energy in Kura-Kura Beach waters is still relatively small.

\section{REFERENCES}

[1] Suriamihardja, D. (2005). Chapter 18" Compromise Management" in the Jeneberang Delta and Losari Bay, Makassar. Department of Geography Publication Series-University of Waterloo, 61: 483.

[2] Sakka, S. (2012). Model Perubahan Garis Pantai di Sekitar Delta Sungai Jeneberang, Makassar, Sulawesi Selatan (Doctoral dissertation, Bogor Agricultural University).

[3] Bakosurtanal. (2007). Prediksi Pasang Surut 2008. Bidang Medan Gaya Berat dan Pasang Surut, 
Pusat Geodesi dan Geodinamika: Cibinong.

[4] Al Tanto, T., Husrin, S., Wisha, U. J., Putra, A., \& Putri, R. K. (2016). Karakteristik Oseanografi Fisik (Batimetri, Pasang Surut, Gelombang Signifikan dan Arus Laut) Perairan Teluk Bungus. Jurnal Kelautan: Indonesian Journal of Marine Science and Technology, 9(2): 107-121.

[5] Kurniawan, L. P., \& Sarwito, S. (2014). Studi Perancangan Prototype Pembangkit Listrik Tenaga Gelombang Laut Tipe Salter Duck. Jurnal Teknik ITS, 3(1): G76-G79.

[6] Budiman, A. S. (2015). Pemodelan Hidrodinamika Pasang Surut Teluk Mayalibit Kabupaten Raja Ampat Provinsi Papua Barat. (Magister thesis, Bogor Agricultural University).

[7] Kushadiwijayanto, A., Apriansyah., \& Idiawati, N. (2017). Pemodelan Arus Musiman Di Perairan Lemukutan Kalimanatan Barat. In PROSIDING SEMIRATA. Universitas Jambi: Jambi.

[8] Pamungkas, A. (2018). Karakteristik parameter oseanografi (pasang-surut, arus, dan gelombang) di Perairan Utara dan Selatan Pulau Bangka. Buletin Oseanografi Marina, 7(1): 51-58.

[9] Yulius, Y., Heriati, A., Mustikasari, E., \& Zahara, R. I. (2017). Karakteristik Pasang Surut Dan Gelombang Di Perairan Teluk Saleh, Nusa Tenggara Barat. Jurnal Segara, 13(1): 65-73

[10] Erofeeva, S. Y., Egbert, G. D., \& Kosro, P. M. (2003). Tidal currents on the central Oregon shelf: Models, data, and assimilation. Journal of Geophysical Research: Oceans, 108(C5): 3148.

[11] Wyrtki, K. (1961). Physical Oceanography of Southeast Asean Waters. Naga Report. I. 2. The University of California, La Jolla.

[12] Triatmodjo, B. (1999). Teknik Pantai. Yogyakarta: Beta Offset.

[13] (USACE) United States Army Corps of Engineers. (2003). Coastal Hydrodinamics Part II, Coastal Sediment Processes Part III. Department of the Army. US Army Corps of Engineers. Washington DC.

[14] Noya, Y. (2009). Estimasi energi gelombang pada musim timur dan musim barat di perairan pantai Desa Tawiri, Teluk Ambon Bagian Luar. Jurnal Triton, 5(2): 43-4.

[15] Apriansyah, A., Kushadijayanto, A. A., \& Risko, R. (2019). Pengaruh Gelombang pada Perubahan Garis Pantai di Perairan Batu Burung Singkawang, Kalimantan Barat. POSITRON, 9(1): 1-7.

[16] Thurman, H. V. (2007). Introductory oceanography. New York: Prentice Hall.

[17] Tarhadi, T., Indrayanti, E., \& Anugroho, A. (2014). Studi Pola dan Karateristik Arus Laut di Perairan Kaliwungu Kendal Jawa Tengah pada Musim Peralihan I. Journal of Oceanography, 3(1): 16-25.

[18] Mardiansyah, L. A., Ismanto, A., \& Setyawan, W. B. (2014). Kajian Potensi Gelombang Laut Sebagai Sumber Energi Alternatif Pembangkit Listrik Tenaga Gelombang Laut (PLTGL) dengan Sistem Oscilatting Water Column (OWC) Di Perairan Pantai Bengkulu. Journal of Oceanography, 3(3): 328-337.

[19] Yuwono, N., \& Kodoatie, R. J. (2004). Pengembangan Reklamasi Pantai dan Perencanaan Bangunan Pengamannya. Direktorat Bina Teknik, Direktorat Jenderal Sumberdaya Air. Jakarta: Departemen Pekerjaan Umum.

[20] Sorensen, R. M. (2006). Basic Coastal Engineering. 3rd Edition. Department of Civil and Environmental Engineering Lehigh University. Bethlehem : Pennsylvania.

[21] Nadia, P., Ali, M., \& Besperi, B. (2013). Pengaruh Angin Terhadap Tinggi Gelombang Pada Struktur Bangunan Breakwater di Tapak Paderi Kota Bengkulu. Inersia, Jurnal Teknik Sipil, 5(1): 41-56. 